\title{
The Questionable Case for Using Auctions to Select Lead Counsel
}

\section{Citation}

Lucian Arye Bebchuk, The Questionable Case for Using Auctions to Select Lead Counsel, 80 Wash. U. L. Q. 889 (2002).

\section{Published Version}

http://digitalcommons.law.wustl.edu/lawreview/vol80/iss3/10/

\section{Permanent link}

http://nrs.harvard.edu/urn-3:HUL.InstRepos:12967857

\section{Terms of Use}

This article was downloaded from Harvard University's DASH repository, and is made available under the terms and conditions applicable to Other Posted Material, as set forth at http:// nrs.harvard.edu/urn-3:HUL.InstRepos:dash.current.terms-of-use\#LAA

\section{Share Your Story}

The Harvard community has made this article openly available.

Please share how this access benefits you. Submit a story.

Accessibility 


\section{Washington University Law Review}

Volume 80

Issue 3 Institute for Law and Economic Policy Conference: Litigation in a Free Society

2002

\section{The Questionable Case for Using Auctions to Select Lead Counsel}

Lucian Arye Bebchuk

Follow this and additional works at: http:// digitalcommons.law.wustl.edu/lawreview

Part of the Civil Procedure Commons, and the Legal Profession Commons

\section{Recommended Citation}

Lucian Arye Bebchuk, The Questionable Case for Using Auctions to Select Lead Counsel, 80 WASH. U. L. Q. 889 (2002).

Available at: http://digitalcommons.law.wustl.edu/lawreview/vol80/iss3/10

This work is brought to you free of charge by the Wash U Law Repository. To explore the repository, click here

(http://digitalcommons.law.wustl.edu/). For more information, contact repository@wulaw.wustl.edu 


\title{
THE QUESTIONABLE CASE FOR USING AUCTIONS TO SELECT LEAD COUNSEL
}

\author{
LUCIAN ARYE BEBCHUK*
}

This Article analyzes the shortcomings of using auctions for selecting lead counsel in class action cases. In contrast to what proponents of auctions suggest, the outcome of an auction is likely to diverge considerably from what an informed principal would have chosen. In particular, auctions push the percentage of recovery paid to counsel to the lowest level at which law firms would be willing to take the case. Because of the need to provide counsel with incentives to invest effort and resources, however, the class might well be better served by a higher percentage than this minimum level, and auctions might push fees to levels that are too low. The analyzed problems are ones that arise also in those types of cases for which the use of auctions should be considered according to the recent recommendations of a Task Force report.

\section{INTRODUCTION}

There has been a judicial trend-beginning with Judge Vaughan Walker's well-known ruling in In re Oracle Securities Litigation ${ }^{1}$-in favor of using auctions to select lead counsel in class action cases. ${ }^{2}$ The subject has for some time attracted much attention and debate, ${ }^{3}$ and it was

* William J. Friedman Professor of Law, Economics, and Finance, Harvard Law School; Research Associate, National Bureau of Economic Research and Center for Economic Policy Research. This Article is based on a statement I submitted to the Third Circuit Taskforce on Selection of Class Counsel; this statement was in turn based on a declaration submitted at the request of counsel for the MicroStrategy Plaintiffs' Group in the case Costaldo v. Microstrategy Inc. I am grateful to Guy Halfteck and Assaf Hamdani for their helpful suggestions and to the John M. Olin Center for Law, Economics, and Business at Harvard Law School for its financial support.

1. See In re Oracle Sec. Litig., 131 F.R.D. 688 (N.D. Cal. 1990); 132 F.R.D. 538 (N.D. Cal. 1990); 136 F.R.D. 639 (N.D. Cal. 1991). Judge Walker has used the auction device in several subsequent cases, including Wenderhold v. Cylink, 188 F.R.D. 577 (N.D. Cal. 1999); In re California Micro Devices, 168 F.R.D. 257 (N.D. Cal. 1994); In re Wells Fargo Sec. Litig., 157 F.R.D. 467 (N.D. Cal. 1994).

2. Following In re Oracle Sec. Litig., supra note 2, auctions were used to select lead counsel in a number of subsequent cases, including In re Network Assoc. Inc. Sec. Litig., 76 F. Supp. 2 d 1017 (N.D. Cal. 1999); Sherleigh Assocs. LLC v. Windmere-Durable Holdings, Inc., 184 F.R.D. 688 (S.D. Fla. 1999); In re Bank One Shareholders Class Actions, 96 F. Supp. 2d 780 (N.D. Ill. 2000); In re Amino Acid Lysine Antitrust Litig., 918 F. Supp. 1190 (N.D. Ill. 1996); In re Lucent Technologies Inc. Securities Litig., 194 F.R.D. 137 (D.N.J. 2000); In re Cendant Corp. Litig., 182 F.R.D. 144 (D.N.J. 1998); and In re Auction Houses Antitrust Litig., 197 F.R.D. 71 (S.D.N.Y. 2000).

3. See, e.g., John C. Coffee, Jr., “Auction Houses": Legal Ethics and the Class Action, May 18, 2000 N.Y. L.J. 223, (Col. 1); John C. Coffee, Jr., The PSLRA and Auctions, May 17, 2001 N.Y. L.J. 
recently examined by a task force of the Court of Appeals for the Third Circuit. ${ }^{4}$

This Article is based on an analysis that I submitted to the Third Circuit Task Force. ${ }^{5}$ It suggests that, notwithstanding its appeal at first glance, the use of auctions to select counsel in securities class action cases is rather problematic. I argue that the outcome of competitive bidding would not generally be a good proxy for the outcome that would result if the class could act as a single and informed principal to strike a bargain with a potential counsel.

The outcome of competitive bidding might well differ from the one that an informed principal would choose for two reasons. First, competitive bidding would tend to put less weight on the nonprice, qualitative dimensions of the choice of counsel (including the counsel's fit to the case) than would a fully informed and adequate representative acting for the class. Second, even assuming hypothetically that participants in the competitive bidding were identical in all nonprice aspects, competitive bidding might well not serve the interests of the class. Because such bidding would give no weight to the need to provide counsel with incentives, the level of fees produced by competitive bidding might well fall below the optimal level for the class. Both problems indicate that competitive bidding might well operate to reduce the expected recovery and thus adversely affect the interests of the class.

In its report, the Third Circuit Task Force expressed substantial skepticism toward the use of auctions. ${ }^{6}$ However, the report identified a range of cases in which the use of auctions might be warranted. ${ }^{7}$ In the identified cases, various potential problems of auctions do not arise. However, the problems analyzed below are ones that might well arise also in the cases for which the report recommended that courts consider the use

225, (Col. 1); John C. Coffee, Jr., Untangling the “Auction Houses” Aftermath, November 30, 2000 N.Y. L.J. 224, (Col. 3); Jill E. Fisch, Aggregation, Auctions and other Developments in the Selection of Lead Counsel under the PSLRA, 64 LAW \& CONTEMP. PROBS. 101 (2001); Andrew K. Niebler, In Search of Bargained-for Fees for Class Action Plaintiffs' Lawyers: The Promise and Pitfalls of Auctioning the Position of Lead Counsel, 54 Bus. LAW. 763 (1999); Note, Class Auctions: Market Models for Attorneys' Fees in Class Action Litigation, 1134 HARV. L. REV. 1827 (2000); See also Mark Hamblett, Debate over Sotheby's Fee-Auction Plan Persists, November 22, 2000 N.Y.L.J. 224, (Col. 3).

4. See The Third Circuit Task Force Report on Selection of Class Counsel, 74 TEMP. LAW REv. 689 (2002).

5. See Professor Lucian Bebchuk, statement submitted to the Task Force on Selection of Class Counsel (June 2001) (on file with author). See also The Third Circuit Task Force, supra note 4, at 727, 761 (discussing this statement).

6. See The Third Circuit Task Force, supra note 4, at Section VIII.A.

7. See id., Section VIII.B. 
of auctions. Thus, the analysis of this Article supports even greater skepticism toward the use of auctions than the one expressed by the Task Force report.

\section{THE INTERESTS OF THE CLASS}

Those judges that have used competitive bidding have regarded it as a proxy for "the one-to-one lawyer-client agreement in conventional litigation" $"$ or as a process that enables approximating the attorney selection and fee bargain that the class itself would strike if it were able to do so. ${ }^{9}$ As will be explained below, however, this is not the case. A competitive bidding process would be unlikely to provide such a proxy or approximation to what the class would do if it could act as a single and informed principal or, equivalently, to what an informed and loyal representative of the class would choose.

From the perspective of the class, it would be desirable to select counsel and a fee schedule so as to maximize the expected net recovery for the class. This expected net recovery is in turn equal to (i) the expected recovery in the case, minus (ii) the expected expenditure on legal representation. The expenditure on legal representation includes both attorney fees and expenses; for simplicity, I will focus below on attorney fees.

The argument for competitive bidding is based on the appeal of reducing attorney fees. It would be in the interest of the class, so the argument goes, to reduce such fees as much as possible. Competitive bidding can push down these fees and, it is argued, such reduction cannot but benefit the class. On this view, the fees from competitive bidding would cost the class far less than the legal fees that could be expected to be sought in an ordinary end-of-case settlement proceeding or fee application.

Reducing attorney fees would, by definition, serve the class in hypothetical circumstances in which the expected recovery could be regarded as fixed. Suppose that everything that the selected counsel will have to do could be completely specified in advance and that any accepted bid would accordingly produce exactly the same expected recovery. In such an imaginary situation, the class interest could indeed be reduced to that of minimizing attorney fees.

The expected recovery in class action cases, however, should not be

8. See In re Bank One Shareholders Class Actions, supra note 2.

9. See In re Wells Fargo Sec. Litig., 157 F.R.D. 467 (N.D. Cal. 1994). 
regarded as fixed. Rather, it is likely to be influenced by the use of competitive bidding. Thus, whether bidding would benefit the class would depend not only on the bidding's effects on attorney fees but also on its effects on the expected recovery.

Competitive bidding might well operate to reduce the expected recovery in two ways. First, by focusing on which bid offers the lowest fee, competitive bidding would likely give insufficient weight to nonprice, qualitative dimensions of the contestants. Second, even assuming that all potential bidders are identical in their nonprice, qualitative dimensions, the push by competitive bidding toward lower counsel fees could, by reducing the chosen counsel's incentives, potentially harm, rather than benefit, the interests of the class. I will now turn to examine each of these two problems.

\section{QUALITATIVE DimENSIONS OF THE CHOICE OF LEAD COUNSEL}

The expected recovery is likely to depend on many nonprice, qualitative attributes of the chosen lead counsel. For simplicity, I will refer to the set of all these attributes as "quality." The term "quality," as defined here, is clearly very broad and includes more than is captured by the ordinary use of the word "quality." ${ }^{10}$ It includes not only how experienced and skilled a firm is (in litigation in general and in litigating similar cases in particular), but also all other attributes that can influence the expected recovery. Thus, for example, quality here includes all the attributes of a firm that could affect its bargaining power, such as reputational capital (known as "tough" in bargaining) or financial resources (which again can strengthen one's bargaining position). It also includes all the attributes that affect the "fit" that a selected counsel would have with the lead plaintiff, since such fit might affect the working relationship between counsel and lead plaintiff.

Clearly, an informed principal choosing an attorney for a complex litigation would pay close attention to the above multiple dimensions of quality. Similarly, an informed lead plaintiff with perfect overlap of interest with the class can be expected to give much weight to such considerations.

10. Cf. Proposed Amendments to FED. R. CIV. P. 23, 23(g)(2)(B), available at www.uscourts.gov/rules/comment2002/B-OICV.pdf ("In appointing an attorney class counsel, the court must consider (i) counsel's experience in handling class actions and other complex litigation, ... and (iii) the resources counsel will commit to representing the class, and may consider any other matter pertinent to counsel's ability to fairly and adequately represent the interests of the class"). 
In contrast, a competitive bidding process would focus primarily on a price comparison. Even Judge Walker, who put forward the use of competitive bidding in In re Oracle Securities Litigation, had to conclude, after trying to have a full comparison of the bids in terms of their nonprice dimensions, that such a comparison by the judge selecting the winning bid is not practical. ${ }^{11}$

To be sure, a court can, as courts have done in the past, limit participation in the contest to bidders that pass a threshold of qualification. But eliminating unqualified candidates still does not give as much weight to quality considerations as an informed client or informed lead plaintiff would be likely to do. An informed client or lead plaintiff would also give weight to differences among those candidates that pass-but to an extent that might vary - the threshold of minimal qualification.

Thus, competitive bidding raises the concern that it would give too little weight to qualitative considerations relative to the interest of the class. Because of this underweighting, selection by competitive bidding might not produce the most fitting lead counsel-and for this reason such method of selection might not be preferred by a lead plaintiff that is well informed and has the class interest in mind.

\section{INCENTIVES}

Turning now to the second problem with selection by competitive bidding, let us put aside the problem of qualitative attributes by assuming below, ipso facto, that all candidates for the lead counsel position (or at least all those passing the minimal threshold of qualification) are identical in all qualitative dimensions, including their fit to the case and to the lead plaintiff. Even under this assumption, selection by competitive bidding might well not be in the interests of the class. To be sure, the competitive bidding process might lead to a reduction in counsel's percentage of the recovery. ${ }^{12}$ But this reduction might be counterproductive rather than beneficial. It might reduce this percentage below the level that would be optimal for the class (in terms of maximizing its expected net recovery).

It is generally recognized that in the context of complex class action litigation, counsel for the class is bound to have substantial discretion

11. See In re Oracle Sec. Litig., supra note 1, at 542.

12. For example, the attorneys' fee award in the Cendant case was slightly above $8 \%$ of the aggregate recovery. See, Coffee, The PSLRA and Auctions, supra note 3. This award, though yielding not less than $\$ 262$ million in attorneys' fees, is a significantly lower percent than the benchmark range of $25 \%$ to $33 \%$. 
(even with monitoring by an effective lead plaintiff) and counsel's incentives are therefore important. ${ }^{13}$ In particular, it is important to provide counsel with strong incentives to make those large investments of time and effort that could serve the interests of the class as the litigation unfolds. To be sure, it can be expected that counsel would make the investment needed to satisfy what is required by the requirement of professional ethics and by reputational concerns. But it would often be desirable to have counsel make investments substantially above the floor established by ethical constraints and reputational considerations. And given that counsel is likely to be best informed about the cost-benefit calculus for such additional investments, a substantial degree of counsel discretion in this matter is inevitable. It follows that, to encourage counsel to make significant investments above the floor established by ethics and reputation, the incentives provided to counsel by the fee schedule can be quite important.

Essentially, the problem of providing incentives to the class counsel is a special case of what economists refer to as the "principal-agent problem." Whenever one party (the "agent" and, in our context, the counsel for the class) must exert effort for the benefit of another party (the "principal" and, in our context, the class), it is important to set a fee schedule that would provide the agent with the appropriate incentives. It is generally the case that no incentive schedule can be expected to eliminate completely the "agency problem"- the concern that the interests of the agent and the principal will not completely overlap. The question is which incentive scheme would be best in reducing "agency costs" - costs from the agent's suboptimal performance. And the optimal incentive scheme might often be one that would provide the agent with more than the bare minimum necessary for the agent take the position.

What competitive bidding would do, and wherein lies its alleged advantage, is reduce the percentage of recovery that the selected counsel would get. Such a bidding process would indeed reduce this percentage to the lowest level that a law firm could get and still cover the value of its investment. But this low percentage, while reducing the fee that the law firm will get, might be below the optimal level for the class because of the

13. See, e.g., John C. Coffee, Jr., The Regulation of Entrepreneurial Litigation: Balancing Fairness and Efficiency in the Large Class Action, 54 U. CHI. L. REV. 877 (1987); Jonathan R. Macey $\&$ Geoffrey P. Miller, The Plaintiff's Attorney's Role in Class Action and Derivative Litigation: Economic Analysis and Recommendations for Reform, 58 U. CHI. L. REV. 1 (1991).

14. See, e.g., Steven Shavell, Risk Sharing and Incentives in the Principal and Agent Relationship, 10 BELL J. ECON. 55 (1979). 
weakened incentives that it would provide. And the loss to the class from these weakened incentives and the smaller expected recovery associated with them, might exceed the savings from lower attorney fees.

To illustrate this point, let us consider a numerical example. Suppose that all qualified law firms are identical. Suppose further that the case of the class is such that, with a time investment of $\$ 150,000$ by counsel (an investment which is assumed to be sufficient to satisfy applicable professional ethics constraints), the expected recovery will be $\$ 1,000,000$. Suppose further that, with an additional time investment of $\$ 250,000$ (an "all-out" effort), the expected recovery in the case will increase to $\$ 2,000,000$.

Consider now the outcome of competitive bidding, assuming for simplicity that bids are in the form of straight percentages of the recovery. The competitive bidding process would push bidders to offer a percentage at the lowest level that would still provide them with compensation for the time they expect to invest. In our example this level is $15 \%$ : contenders would know that if they get the case on a $15 \%$ contingency, they will make a time investment of $\$ 150,000$, and they will get $15 \%$ of the expected recovery of $\$ 1,000,000$ with such an investment.

Note that, with a winning bid of $15 \%$, the selected counsel will not make the additional $\$ 250,000$ investment involved in an all-out effort. Such an investment would increase expected recovery by $\$ 1,000,000$ and (given the $15 \%$ contingent fee) would increase the counsel's expected fees by only $\$ 150,000$ - less than the $\$ 250,000$ additional investment by counsel involved in an all-out effort. Thus, with a competitive bidding process, the winning bid would be one demanding a $15 \%$ contingency, the expected recovery would be $\$ 1,000,000$, and the net expected recovery to the class would be $85 \%$ of $\$ 1,000,000$ or $\$ 850,000$.

Consider next how the class would fare if the selected counsel were given a contingent fee of $25 \%$ rather than $15 \%$. In this case, the selected law firm would elect to make not only the $\$ 150,000$ investment but also the $\$ 250,000$ investment needed for an all-out effort. Given that the law firm can expect to get $25 \%$ of the extra $\$ 1,000,000$ in expected recovery produced by the $\$ 250,000$ additional investment, the firm would expect to be compensated for making the all-out effort. As a result, the expected recovery would be $\$ 2,000,000$, and after the $25 \%$ fee, the net expected recovery to the class would be $\$ 1,500,000$.

Thus, in the case under consideration, compared with a contingent fee of $25 \%$, competitive bidding would reduce counsel's percentage to $15 \%$ and counsel's expected fees from $\$ 500,000$ to $\$ 150,000$. But this reduction would overall not be in the best interests of the class. It would decrease the 
expected net recovery to the class from $\$ 1,500,000$ to $\$ 850,000$ (a reduction of about $43 \%$ ). Compared with setting a fee of $25 \%$, the competitive bidding process would make the class worse off because, by eliminating the incentive to invest in an all-out effort, it would reduce the expected recovery by an amount exceeding the savings from lowering counsel fees.

The above example, of course, is not intended to imply that $25 \%$ is the optimal percentage in all or most cases. An article by Bruce Hay develops a systematic economic analysis of the optimal contingent fee that an informed client hiring a contingent fee lawyer would set. ${ }^{15}$ Hay shows that such a client would take into account two competing goals: (i) providing counsel with incentives to exert effort, and (ii) reducing any profits to the counsel above the compensation needed for the counsel's investment of time (profits that Hay labels the lawyer's "rent"). Any increase in the lawyer's percentage might, on the one hand, improve the lawyer's incentives but might, on the other hand, increase the lawyer's profit (rent). Trading off these two competing considerations provides the optimal contingency fee, which might well depend on the characteristics of the case and thus vary from case to case. In a class action situation, the aim of the lead plaintiff and the court should be to get as close as possible to the optimal fee schedule that an informed principal would set to balance these two goals.

The above analysis and illustrating example, then, point out that the optimal fee is one that gives weight to both (i) savings to the class from reducing attorney fees, and (ii) benefits to the class from providing strong incentives to its counsel. While an informed client or lead plaintiff would give weight to both considerations (i) and (ii), competitive bidding would focus solely on (i) and thus might result in a fee schedule that is too low compared with the schedule optimal for the class.

Indeed, in one basic model analyzed by Hay, the optimal contingent fee is generally above the break-even level that leaves the lawyer with no rent and that would be produced by a bidding contest. ${ }^{16}$ There is thus reason to be concerned that the fee level set by competitive bidding would often be below what would be optimal for the class. This would be especially likely to happen whenever consideration of incentives are sufficiently significant, i.e., whenever the expected recovery is sufficiently influenced by counsel's investment of effort and time.

15. See Bruce L. Hay, Contingent Fees and Agency Costs, 25 J. Legal Stud. 503 (1996).

16. Id. at 519-20. 


\section{MORE COMPLEX AuCTIONS}

The analysis above assumed for simplicity that the bidding contest would take the form of each firm proposing a straight fee. But the point made above - that the effect of competitive bidding on reducing counsel fees might have significant costs in terms of incentives-would also apply to other, more complex forms of competitive bidding.

Consider, for example, a format under which bidders are asked to submit proposals for a minimum recovery from which they will not take any fees. In the antitrust suit against Sotheby's and Christie's auction houses, the judge asked law firms to state a figure $X$ from which they are prepared not to take any fees. ${ }^{17}$ The winning bidder submitting the highest $X$ would receive no fees from any recovery up to this submitted $X$ and $25 \%$ from any amount recovered above $X{ }^{18}$ Under such a format, the competitive bidding process would push lawyers to raise $\mathrm{X}$-which is essentially to reduce to zero their share of any dollar of recovery below $X$. Again, while such bidding could lower the selected counsel's total fees, it might produce adverse incentives whose costs would outweigh the savings to the class from these lower fees.

To see that having a large $X$ might be a rather mixed blessing, consider a counsel that was selected on the basis of commitment to taking no fees from any recovery up to $\$ 100,000,000$ and to getting $25 \%$ of any amount exceeding $\$ 100,000,000$. To see the potential for perverse incentives, suppose that the case does not proceed well and that the expected recovery falls below $\$ 100,000,000$. In such a case, the minimum recovery feature might eliminate any financial incentive to exert effort that the counsel might otherwise have.

Relatedly, the minimum recovery feature might provide adverse incentives with respect to settlement decisions. In the considered example, accepting a settlement offer of, say, $\$ 90,000,000$ would never be in the interest of the lawyer. This would be the case even when such acceptance would be in the interest of the class - say, because a trial would be expected at the time to produce a $50 \%$ chance of $\$ 150,000,000$ recovery and a $50 \%$ chance of zero recovery.

17. See In re Auction Houses Antitrust Litig., 197 F.R.D. 71, 73 et seq. (S.D.N.Y. 2000).

18. See Judge Revises Lead Counsel Auction Plan, May 19, 2000 N.Y. L.J. 223, (col. 5). 


\section{WHY AN INFORMED AND LOYAL LEAD PLAINTIFF Might DiSFAVOR COMPETITIVE BIDDING}

To see the shortcomings of selection through competitive bidding in yet another way, consider situations in other contexts in which a principal hires an agent for a complex task that cannot be fully specified in advance. Consider, for example, a venture capitalist that controls a high-tech startup and seeks a CEO to manage it in its next stage. The CEO is to be compensated primarily in options on the company's stock. Would the venture capitalist likely select the CEO by having competitive bidding among the qualified candidates and hiring the candidate who is willing to take the job for the smallest number of options? Hardly.

The reason why a venture capitalist in such a situation cannot be generally expected to use such competitive bidding lies in the two issues of quality and incentives that I have discussed in the preceding sections. First, the venture capitalist might wish to give some substantial weight to how the qualified candidates (those passing the threshold of qualifications based on their CVs) might differ in the many relevant dimensions of quality, including their fit to the company and to working with the venture capitalist. Second, the venture capitalist might prefer to grant the CEO the smallest number of options that would be needed to induce the CEO to take the job; the venture capitalist might choose to provide the CEO with more options in order to provide more high-powered incentives. ${ }^{19}$

Similarly, an informed lead plaintiff who has only the interests of the class in mind might prefer not to have the compensation of the lead counsel set at the break-even rate that a competitive bidding can be expected to produce. While such bidding might push down the selected counsel's percentage of recovery, it might actually push it to a level below the one that is optimal for the class.

Supporters of bidding have suggested that a plaintiff that does not support selection through competitive bidding cannot be an adequate lead plaintiff. Conversely, on their view, a plaintiff's support for such bidding provides an indication that this plaintiff would be an adequate lead plaintiff. But the above analysis indicates that this is not the case. The interests of a class could well be ill-served by having selection through competitive bidding. Opposing such bidding by a potential lead plaintiff

19. Similarly, boards of directors that set the options grants to executives of publicly traded companies can be expected to ask not only how much would be needed to keep the executive but also what options grants would be beneficial in terms of providing the executive with appropriate incentives. 
thus does not at all indicate that this plaintiff would not be an informed and loyal representative of the class.

\section{CONCLUSION}

This Article has suggested that, notwithstanding the appeal that auctions for selecting class counsel might have at first sight, this mechanism is in fact problematic. In contrast to what has been often argued, such auctions cannot be expected to approximate the outcome that would result if the class could act in an informed manner to strike a bargain with a potential counsel. First, competitive bidding would tend to attach too little weight to nonprice, qualitative dimensions of the choice of counsel. Secondly, competitive bidding would not give sufficient weight to the need to provide the class counsel with appropriate incentives. Competitive bidding would push outcomes toward the minimum level of fees that would be sufficient to make it worthwhile for counsel to take the case. This minimum level of fees, however, might be one that would induce little effort and investment by counsel and thereby undermine rather than serve the interests of the class. 